\title{
Community Inhabitants' Attitudes on the Partitioning of Urban Space Derived from South-Eastern Asian Migrant Workers' Gathering in Urban Commercial Area-A Case Study on Tainan City, Kaohsiung City and Taichung City in Taiwan
}

\author{
Kung-Hung Chen \\ Graduate Institute of Taiwan Culture, National University of Tainan, Taiwan \\ Email: hung@mail.nutn.edu.tw
}

Received October $5^{\text {th }}, 2013$; revised November $24^{\text {th }}, 2013$; accepted December $11^{\text {th }}, 2013$

Copyright $@ 2014$ Kung-Hung Chen. This is an open access article distributed under the Creative Commons Attribution License, which permits unrestricted use, distribution, and reproduction in any medium, provided the original work is properly cited. In accordance of the Creative Commons Attribution License all Copyrights @ 2014 are reserved for SCIRP and the owner of the intellectual property Kung-Hung Chen. All Copyright (C 2014 are guarded by law and by SCIRP as a guardian.

\begin{abstract}
This study is to explore south-eastern Asian migrant workers' impacts and their influential factors of gathering/consumption activities on divided cities in Tainan City, Kaohsiung City and Taichung City. We will take on an empirical study in the cities' commercial area or shopping street in three cities. Three major research methods are applied, including questionnaire survey, participant observation and regression analysis. Data will be obtained from the questionnaire answers of local inhabitants and analysed via SPSS10.3 statistical methods. The main outcomes of this study are as follows: 1) In Tainan City, Kaohsiung City and Taichung City, we have found that the partitioning of urban space has begun to become. Among this, the outcome of Taichung City is much stronger than that of the two other cities. 2) In the impacts of migrant workers' gathering on commercial streets, community inhabitants also have more tolerant attitude than shop keepers. The community inhabitants of Taichung City have more hostile than those of the two other cities. 3) In comparison of South-eastern Asian migrant workers' gathering in urban commercial area and its relations between the partitioning of urban space, from the viewpoint of local inhabitants, we have found different influential factors among Tainan City, Kaohsiung City and Taichung City. We can say that these factors will be valid predictable variables on divided cities resulted from migrant workers' gathering/consumption activities in the paper. In the meantime, we can obtain these influential factors among these three cities through two variables: 1) community inhabitants' socio-economic attributes and 2) community inhabitants' responses to migrant workers' gathering/consumption activities in commercial area. Basically we can find these influential factors among the paper which are the same as the Netherlands and Singapore, and not the same as Guangzhou, China.
\end{abstract}

Keywords: Gathering of South-Eastern Asian Migrant Workers; Partitioning of Urban Space; Tainan City; Kaohsiung City, Taichung City

\section{Introduction}

According to the statistic data of Bureau of Employment and Vocational Training, from at the end of September, 2011, it is indicated that the total amount of migrant workers in Taiwan and Fukien area is 417,844, including Tainan City with 30,237 people, Kaohsiung city with 30,394 people, and Taichung city with 56,374 people. (These three cities that are mentioned above are after merger upgraded to municipalities). Saskia Sassen $(1988,1991,1996)$ clearly analyzed in many of her writings how migrant workers, in the era of globalization and economic dynamism, created new global cities and how this kind of largescale flow of capital and human resources inevitably causes a great impact on residential countries urban spaces. As a series of researches about "Divided Cities” by Peter Marcuse (2002) proposed, it is more obvious to notice that, in the global market economy, the spatial structures which are the spaces for pro- duction, consumption and living are formed by people in different economic classes. Thus, the effects on the migrant workers versus the spatial development of commercial communities and the changes of the space axis are really interesting and have significant academic meanings for the researches of metropolitan spaces. In other foreign countries, the empirical researches, which relate to the ideas of "Divided Cities", are more exuberant and complete, but less direct to the factors of the space division of cities. In Taiwan, most of the empirical researches are concerning the distribution of the gatherings and consumption activities of migrant workers in the cities, as well as the aspects of socialized spaces. Thus, to explore from community residents' points of view, how migrant workers from Southeast Asia's gathering cause an effect on urban space division is not only the characteristic of this paper, but also the research motivation of this paper. 
In this paper, we use the concept called "divided cities", proposed by Peter Marcuse to see how local community residents' attitude changes and their responses to the inflow of different cultural groups impact on urban space division, and to investigate, analyze and interpret how migrant workers' consumption activities cause an effect on urban community space. We use 3 of Taiwan's biggest cities, Tainan city, Kaohsiung City and Taichung city as our objects of research, which is also the purpose of this study.

\section{Literature Review}

In other countries, the empirical studies about the concept of "divided cities" are richer and more complete, but however, they rarely focus directly on urban space division's influencing factors' studies. Therefore, we introduce the cases as following:

\section{Netherlands}

In his paper called "Towards Partitioned Cities in the Netherlands” (2002), Ronald van Kempen targeted the changes of patterns of urban space's segment in a well-developed welfare state - the Netherlands. He found that, in the Netherlands, so called "partitioned cities" have become a more and more obvious trend and they have been developing rapidly. Apart from the changing role of the government, the change of economic, population and socio-cultural factors must be taken into account as well (Marcuse \& Kempen, 2002). In the Netherlands, metropolis of ethnic minorities', segmentation and concentrated phenomena are very obvious. In recent years, a large number of migrants moved to the Netherlands, and they also entered its labor market to look for jobs, this phenomenon has been continuing to expand, due to the supply and demand imbalance, it leads to the result of persistent structural unemployment. Migrants (Especially Turkish and Moroccan) also suffer from this development, many low-skilled migrants must rely on state support in order to survive, more and more phenomena of "partitioned cities" are resulting from the welfare state's recession, which leads to the results of social and spatial problems. In short, the factors that made the Netherland's "partitioned cities" phenomenon so obvious are: the changing role of government, economic, demographic, socio-cultural changes, employment rate and the level of income.

\section{Singapore}

Brenda Yeoh and Shirlena Huang (1998), in the study of housework female migrant workers' taken in strategies and types in the Singapore's public space, by viewing the social map of these migrant workers, it can be seen how it has been structured and compromised on public space and investigated how these migrant workers, viewed as margins of society in Singapore built their urban landscape. They found out, in capitalist, so-called "partitioned cities" reflect more clearly and strengthen the gender division of labor as well as the characteristics of daily live experience. It not only presented the space by the traditional patriarchy, but also presented by the space of racial factors and other means of isolation, to expand it. This study indicated that these housework female migrant workers aren't entirely passive recipients of dominant practice and ideas, in fact, they are capable of taking a variety of different ways and strategies to use and compete the public space.

Their research based on public domain's points of view is based on the following: 1) deprived of space and 2) competition of space, in order to analyze them. The former, use Filipino housework labor's gathering and all kinds of consumption activities in the shopping mall- "Lucky Plaza”, as the research's main focus. The shopping mall- "Lucky Plaza”, has become like "little Manila". Over the weekend, there are around 2000 Filipino female migrant workers gathering in this area. Thus, the Filipino migrant workers have caused the colonization trend of this public space. Gradually, as for some Singaporeans, "Lucky Plaza" has been a "partitioned city", changing from an "other type of space" to a "hesitant space". The latter, by the limitations of "other type of space", the female migrant workers can still make differences by managing their ways of living their daily life, including understanding how to define and use space well, we'll use this concept as our entry point, in order to analyze the so-called "competitive space”. In short, the influencing factors that made Singapore's "Lucky Plaza” become such an obvious "partitioned city", included not only a laissez-faire government, but also the tolerance of the community residents, and most importantly, how these Filipino migrant workers used "competitive space” as means to colonize this pubic space.

\section{Guangzhou, China}

Huimin Du and Si-ming Li (2010), have been observing China's economic reform and the process of urbanization. In recent years, millions of migrant workers came from the countryside to the big cities in China, and they have become an important part of the labor force of the cities, and eventually shaped the so-called "urban villages". In this development trend, both of them focus on the "urban villages" laborers' socioeconomic background, life satisfaction, living environments etc., to describe the situations in detail, and at the same time use "community satisfaction" and "community contacts" to explore the emotions of these "urban villages" laborer's emotions about the community.

The research findings show that "urban villages" not only provide a place to live, but the laborers of the "urban villages" also use various ways to integrate in the cities. Community sentiment is mainly based on labor's cognition on neighborhood environment quality and neighborhood relationships, in addition, the effect of local participation and migrants social networks also gradually unfolded. Participating in local affairs bring residents a higher level of community satisfaction, however, participating in local affairs doesn't have a statistically significant difference on degrees of community contact; likewise, the migrant social network theory can also explain community sentiment, it can fully support community satisfaction, rather than degrees of community contacts. In short, the reasons why Guangzhou, China's “urban villages” phenomenon seems so similar to "partitioned cities" are mainly because of: good cognition on neighborhood relationships, public participation, migrant social network, etc. But the Netherlands and Singapore's cases' migrant socio-economic attributes and roles of government are comparably less important.

In Taiwan, the empirical researches about the concept of "divided cities or partitioned cities" are relatively few. Most of the very few researches are about migrant workers gathering, their consumption activities' distribution in the urban space and their socialized space field kind of researches. For example: The first paper in Taiwan that studied about migrant worker's space issue was written by Sheu, Horng-Yih in 2000. It is called "The 
use of Space and Its Effect in a Filipino Labor Gathering Area -Christopher Church Area on Chung-Shane North Road”. He saw the migrant workers from an urban point of view, and use "Filipinize" to interpret the Filipino migrant workers impact on Chung-Shan North Road, focusing the study on Filipino migrant workers space conflict with the city residents, and finally concluded that the public sector should intervene to control it as a policy recommendation. Wu Bi-nar's thesis (2003), “ChungShan-The Formation of a Filipino Migrant Workers' Community Space in Taipei”, basically compared with Sheu, HorngYih's paper, has a better insight on Filipino migrant workers relationship with the space., By gathering around Christopher church area in a common space-time and the entering of surrounding shops, Chungshan is where displaced Filipino migrant workers can re-territorialize the space. This space has given rise to richer and more diversely activities, it not only satisfies the Filipino migrant worker's transnational life needs in Taiwan, it also became Filipino labor community's leisure, consumption and cultural center. In one of Pei-Chia Lan's paper (2002) called "A Transnational Topography for the Migration and Identification of Filipino Migrant Domestic Workers", we found out they perform multiple roles and shifting identities through the front/backstage segregation in social space (working days vs. rest day; home country vs. host country), isolating labor and consumption activities, and the differentiation of temporal horizons (now vs. future) in order to build floating identification. In Chou Cheng-Hung's thesis called "Migrant labors: a catalyst for rebuilding urban space”, he found out that migrant workers always appear at a certain time, which alienates the urban space, the ethnic contact, cultural contact and the overlapping use of objects' process generates a "critical space", by walking the delicate balance between public, privacy, other people and ourselves. This paper is noteworthy because it has some similarities to our research of Qixian 3rd Road, Kaohsiung city’s observed phenomenon, thus, it has a higher reference value. Chih-Hung Wang (2006), used "Dis/placed Identification and Politics of Space: The Consumptive Ethnoscape around Taoyuan Railroad Station” to explore what kinds of social tension and conflicts are derived from the formation of Southeast Asian consumptive ethnoscape around Tao-Yuan railroad station. And how do these tensions and conflicts appear as contention about uses and meanings of space? What the relation between the formation of consumptive ethnoscape and the negotiation is of dis/placed identities, as well as various stores and police control? Such topics are worth being referenced. Chen Kung-Hung's (2011a-2011c, Chen, 2008) research is different from the previous studies because he advocates: the original existence of the urban business district and its' surrounding communities' local community residents and shop owners, their original life style and shop's mode of operation will change because immigration of different cultural groups, will bring influence and change on its culture and space, their way of presenting changes of lives, culture and space are called the "result" of "transnational space" or "divided space". Under the concept of "transnational space" or "divided space", the paper focuses on the attitudes of local community residents and shop owners toward the impacts of immigration of different cultural groups, of urban space partitioning and it also explains the degrees of "partitioning of urban space". It emphasis the main research orientation on "urban business district's migrant workers gathering caused partitioning of urban space phenomenon", it's an innovative area of research, which is worthy of attention.
Based on the literature, theories and related researches above, we believe, there are some points in common:

1) Based on the theory of "migrant workers, in the era of globalization and economic dynamism, created a large-scale flow of capital and human resources, they inevitably cause a great impact on residential countries' urban space”. This is the context that so-called "transnational space" and "space partitioning” form, it belongs to global macro kind of driving force.

2) Based on daily life, leisure, shopping and religion needs, migrant workers naturally have to gather in the business districts and do consumption activities, and their consumption activities have become urban community space's "outside invader", "influencer", this is the reason why the "transnational space" or "space partitioning" is formed. Furthermore, local community residents living in the business districts as well as surrounding communities' local residents have changed their ways of living and the ways of using the space due to the impacts of immigration of different cultural groups on culture and space. Based on the impact of urban community space, they have become migrant worker's consumption activities' "local insiders", "influence", at the same time, their ways of presenting their changes of life, culture and space are the results of "transnational space" or "space partitioning".

3) In view of the above cases, they're in fact all the same regardless of space, which can be the evidence of the "causes" and "results" that were mentioned above. These "causes" and "results" are the research motivations. This paper's main purpose is also based on the concept of "transnational space" or "space partitioning", to conduct investigations, analysis and interpret the feelings of migrant workers' space usage, the attitude of the local community residents toward the impacts of immigration of different cultural groups of urban space partitioning, and the influencing factors of migrant workers' consumption activities to the community space.

\section{Theoretical Framework}

According to Figure 1, we can propose some hypotheses of the research as follows.

Hypothesis 1:

The attitude of the local community residents toward the impacts of immigration of different cultural groups of urban space partitioning is an important influencing factor of the level of urban partitioning.

Hypothesis 2:

Community inhabitants' socio-economic attributes are important influencing factors of the level of urban partitioning.

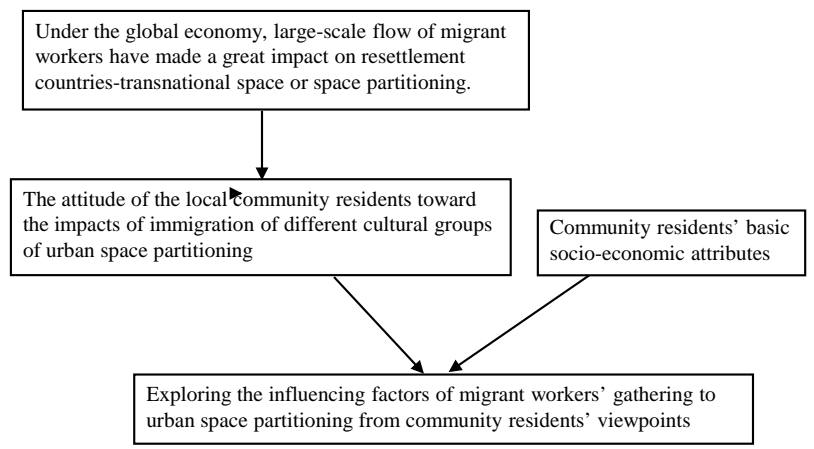

Figure 1.

Theoretical framework. 


\section{Research Methods and Content}

\section{Research Methods}

The required information comes from local community residents of Tainan, Kaohsiung, and Taichung City. These members of the community live around the area where Southeast Asian migrant workers like to gather in the business districts. Designing a questionnaire of "urban business district's migrant workers' gathering in urban business districts and the its relations between the partitioning of urban space" (community residents section) as one set, and we'll go to the commercial area for sampling, in order to study the relations between migrant workers' gathering and the partitioning of urban space. The questionnaire's content mainly included: 1) The attitude reflection on migrant workers' weekend gathering and its impact of urban space partitioning, and 2) the basic information of the respondents. About data analysis, we use version 10.3 of SPSS as the statistical software to do the statistical analysis.

\section{Types of Stores in the Research Areas}

In Tainan City, the so-called "Indonesian Migrant Worker Street” refers to the shopping streets around Fu-Bei Street/XiHua Street/Bei-Zhong Street. It currently has a total of 43 shops, including 2 Indonesian restaurants, ENCAR, Ming-Yue Vietnamese restaurant, 2 foreign exchange banks, Yi-li Telecom Service Co., Ya-Jiu food store, 3 Thai restaurants, TK store, Charlie Brown restaurant, EEC store; When adding the 12 stores that are owned by local Tainan shop owners, it has a total number of 26 shops. It contains more than half of the total shops which include a tea shop, a supermarket, a telecom company, a cafeteria, complex restaurants, noodle restaurants, a vegetarian restaurant, the Qiao-Yi kitchen and the Ma-Na restaurant. They've become places where migrant workers (Indonesian-based) often consume at. The stores mainly opened in 2001 in a total number of 26 stores, and 36 rental stores.

In Kaohsiung City, the so-called "Southeast Asian Migrant Worker Street” is mainly around the Kaohsiung Railway Station and the Kaohsiung port area. It's where migrant workers like to gather and shop in Kaohsiung City nowdays. The former includes: 1) Jianguo 3rd Road: a total of 117 stores, 2) ZhongHua 3rd Road: a total of 100 stores, 3) Qi-Xian 1st Road: a total of 26 shops, 4) Qi-Xian 2nd Road: a total of 88 shops, 5) Ba-De 2rd Road: a total of 82 shops, the latter includes Qi-Xian 3rd Road and Bi-Zhong Street, it has a total of 99 shops, but from the interviews of the bosses, there are around 30 shops that Filipino migrant workers rarely go to. And the rest of the 60 shops' main customers are Southeast Asian migrant workers, or the shops that Southeast Asian migrant workers often go to. Among them, Qi-Xian 3rd Road has a total of 46 shops, included 6 shops which owned by Taiwanese boss and hired Southeast Asian as employees, they're Qi-Xian restaurant, Sally mini supermarket, MARINERS eatery, PINOY BISTRO BAR (opened two), and CEBU CITY Korean restaurant; and there are 23 shops on Bi-Zhong Street, including 2 shops owned by Taiwanese bosses which hired Southeast Asian as employees, namely "Wellcome” and "Annie's boracay". Most of the shops have opened in less than 10 years, and half of them rented the place to open up the stores. So, it can be seen that same as in Tainan City, because of migrant workers gathering and consumption in recent years, it's common for non-local residents to come all the way to Kaohsiung City to open up stores.
In Taichung City, it's mainly around the business district opposite the Taichung Railway Station, includes where the migrant workers like to gather and shop most in Taichung City: Taichung First Square/Lu-Chuan Western Street and two shopping streets: Cheng-Kung Road, Chi-Kuang Street: 1) First Square/Lu-Chuan Western Street: They mainly distributed on 1 st to 3nd floor, it has a total of around 120 shops, and there are around 1/4 shops owned by foreigners (Mainly from Southeast Asian countries), the types of shops are mainly restaurants, eatery, shopping malls, and telecom service companies, such as "BIG KING Shopping Mall”, “Indah Counter”, “Tai-Luo 77”, Thailand restaurants, "Vinh Ha Long snack bar”, Vietnamese Restaurants, et al.; 2) Cheng-Kung Road: it has a total of 27 shops, and there are around 6 shops owned by foreigners, such as BOSS STORE, the branch of BOSS STORE, Café Batavia, JASON STORE, 3) Chi-Kuang Street: it has a total of 53 shops, and there are around 2 shops owned by foreigners and Vietnamese snack bar .

\section{Statistical Respondents and Sample Size}

The survey respondents are mainly community residents. In Tainan City, the communities around Fu-Bei Street/Xi-Hua Street/Bei-Zhong Street have a total number of about 380 households, using household as a sampling unit, it has 100 effective samples and thus the sampling ratio is $26.3 \%$. In Kaohsiung City, the "Southeast Asian Migrant Worker Stree" contains 6 migrant worker streets, which have a total number of about 1150 households. Using household as a sampling unit, it has 421 effective samples which results into a sampling ratio of $36.6 \%$. In Taichung City, the "Migrant Worker Street" is around the business district, on the opposite of the Taichung Railway Station, including Taichung First Square/Lu-Chuan Western Street and two shopping streets: Cheng-Kung Road, Chi-Kuang Street, which has a total number of about 1200 households. Using household as a sampling unit, it has 400 effective samples which results into a sampling ratio of $33.3 \%$.

\section{Discussion of Survey Results}

Discussions about the Regression Analysis of Influencing Factors of Migrant Workers' Strong Movement towards Urban Spaces Are Partitioning

\section{1) A. Tainan City}

Seeing from Table 1 and the overall regression model, the overall regression model has an explanatory power $(\mathrm{F}=1.968$, $\mathrm{P}<.05$ ), it can effectively explain why migrant workers have $39.9 \%$ variance as positive impact on consumption activities. Among all these, residence time has reached statistically significance; it's an effective forecasting variable, because $\beta$ is negative. It shows that the longer the residents live in the communities, the less they think migrant workers have positive impact on consumption activities. Moreover, for respondents that work in agriculture, forestry, fishery, and animal husbandry field, it has also reached a statistically significance. It indicates that comparing people who are working in agriculture, forestry, fishery, and animal husbandry field with middle class people, people who work in those fields tend to think that migrant workers have better positive impacts on consumption activities.

At the same time, the standardized regression equation is as following:

$\mathrm{Y}=-.053$ Gender (male) +.201 Age +.221 Educational Level 
Table 1.

Regression coefficient table.

\begin{tabular}{|c|c|c|c|}
\hline Predictor & $\begin{array}{l}\text { Standardized } \\
\text { Regression } \\
\text { Coefficient } \beta\end{array}$ & $\mathbf{t}$ & Significance \\
\hline (Constant) & & 4.154 & .000 \\
\hline Gender (male) & -.053 & -.466 & .643 \\
\hline Age & .201 & 1.360 & 178 \\
\hline Educational Level & .221 & 1.761 & .082 \\
\hline Residence Time & -.246 & -2.056 & $.043^{*}$ \\
\hline Monthly Salary & 167 & 1.516 & .134 \\
\hline Family Structure & -.073 & -.659 & .512 \\
\hline Marriage (unmarried) & .058 & .435 & .665 \\
\hline Marriage (divorced) & .107 & .992 & .324 \\
\hline Religion (Catholic) & -.122 & -1.140 & .258 \\
\hline Religion (Christian) & -.147 & -1.339 & .185 \\
\hline Religion (Taoism) & .134 & 1.193 & .237 \\
\hline Religion (Other) & .058 & .553 & .582 \\
\hline Activity time (noon) & .114 & .792 & .431 \\
\hline Activity time (evening) & -.168 & -1.225 & .225 \\
\hline Activity time (other) & -.235 & -1.747 & .085 \\
\hline $\begin{array}{l}\text { Contact time with the } \\
\text { migrant workers } \\
\text { (weekends or holiday) }\end{array}$ & -.039 & -.267 & .790 \\
\hline $\begin{array}{l}\text { Contact time with } \\
\text { the migrant } \\
\text { workers (other) }\end{array}$ & -.028 & -.193 & .847 \\
\hline $\begin{array}{c}\text { Occupations (agriculture, } \\
\text { forestry, fishery, animal } \\
\text { husbandry) }\end{array}$ & .290 & 2.875 & $.005^{* *}$ \\
\hline Occupations (industries) & -.056 & -.468 & .641 \\
\hline $\begin{array}{c}\text { Occupations } \\
\text { (low-level of white-collar } \\
\text { office labors and low-level } \\
\text { military personnel) }\end{array}$ & .027 & .255 & .799 \\
\hline $\begin{array}{l}\text { Occupations } \\
\text { (high-level of white-collar } \\
\text { labors, middle class) }\end{array}$ & .028 & .240 & .811 \\
\hline $\begin{array}{c}\text { Occupations } \\
\text { (homemaker) }\end{array}$ & -.031 & -.253 & .801 \\
\hline Occupation (none) & .025 & .202 & .840 \\
\hline Occupation (other) & 108 & .857 & .394 \\
\hline $\begin{array}{l}\text { Social-identity from } \\
\text { community residents to } \\
\text { migrant workers }\end{array}$ & .011 & .107 & .915 \\
\hline
\end{tabular}

Note: The dependent variable $\mathrm{Y}$ is the total score of migrant workers positive impacts on commercial activities.

+-.246 Residence Time +.167 monthly salary + - .073 Family Structure, .058 Marriage (Unmarried) +.107 Marriage (Divorced) + - .122 Religion (Catholic) + - .147 Religion (Christian) +.134 Religion (Taoism) +.058 Religion (Other) +.114 Activity time (noon) +-.168 Activity time (evening), -.235 Activity time (other) +-.039 Contact time with the migrant workers (weekends or holiday) +-.028 Contact time with the migrant workers (other) +.290 Occupations (agriculture, fo- restry, fishery, animal husbandry) + - .056 Occupations (industries) +.027 Occupations (low-level of white-collar office labors and low-level military personnel) +.028 Occupations (highlevel of white-collar labors, middle class) +-.031 Occupations (homemaker) +.025 Occupations (none) +.108 Occupations (other) +.011 Social-identity from community residents to migrant workers.

2) Kaohsiung City

Examining Table 2 and the overall regression model, you can see that the overall regression model has an explanatory power $(\mathrm{F}=1.812, \mathrm{P}<.01)$, it can effectively explain why migrant workers have $12.2 \%$ variance on positive impact on consumption activities. Amongst all these, Religion (Islam)'s $\beta=$ -.109 , $(\mathrm{t}=-2.241, \mathrm{p}<.05)$ has reached statistically significance, it's an effective forecasting variable, because $\beta$ is negative, it shows that non-Muslim residents think migrant workers' gathering makes urban space partitioning more serious. Moreover, marriage (Divorced)'s $\beta=-.117,(\mathrm{t}=-2.363, \mathrm{p}<.05)$ has also reached a statistically significance. It indicates that nondivorced residents tend to think migrant workers' gathering makes urban space partitioning more serious. And as for the reason why "Married residents have lower degree of satisfaction to community spatial links" we can find explanations from resident's marriage status and their current family structure. According to the surveyed residents, the proportion of married people is much higher than unmarried and divorced people, because married couples with kids, married couples with kids plus the parents, four generations of families... all these above in total make the proportion higher than others, considering the cultural and spatial impacts due to immigration of different cultural groups, people have to consider the negative impacts that family members will possibly encounter. Usually married people tend to tolerate the situation and even accept it. In other words, it creates a lower degree of satisfaction to community spatial links, and they tend to think it can make urban space partitioning more serious. In the end, residents attitude on migrant workers' $\beta=.121,(t=2.444, p<.05)$ has reached a statistically significance, so it's an effective forecasting variable. It indicates the more positive attitude of residents towards migrant workers gathering, the easier they think it leads to urban space partitioning.

At the same time, the standardized regression equation is as follows:

$\mathrm{Y}=-.070$ Gender +-.149 Age +-.021 Educational Level + -.027 Monthly Salary +-.013 Family Structure, +.043 with or without Migrant Maids Marriage +-.069 Religion (Catholic) + -.041 Religion (Christian) + .002 Religion (Buddhism) +-.109 Religion (Islam) +-.038 Religion (Other) +-.026 Occupations (agriculture, forestry, fishery, animal husbandry) +-.027 Occupations (industries) +.028 Occupations (low-level of whitecollar office labors and low-level military personnel) +-.019 Occupations (high-level of white-collar labors, middle class, high-end military personnel) +-.005 Occupations (Bourgeois, freelancers) +.011 Occupations (big capitalists) +-.021 Occupations (homemaker) +.048 Occupations (none) +-.012 Marriage (Unmarried) +-.117 Marriage (Divorced) + - .060 Activity time (morning) +.077 Activity time (noon) +-.006 Activity time (afternoon) +-.047 Activity time (midnight) +.100 Contact time (morning) +.002 Contact time (Noon) +.015 Contact time (Afternoon) +.009 Activity time (midnight) +.121 Community residents' attitude on migrant workers.

3) Taichung City 
Table 2.

Regression coefficient table.

\begin{tabular}{|c|c|c|c|}
\hline Predictor & $\begin{array}{c}\text { Standardized } \\
\text { regression } \\
\text { coefficient } \beta\end{array}$ & $\mathbf{t}$ & Significance \\
\hline (Constant) & & 11.098 & .000 \\
\hline Gender & -.070 & -1.268 & .206 \\
\hline Age & -.149 & -1.967 & .050 \\
\hline Educational Level & -.021 & -.390 & .697 \\
\hline Monthly Salary & -.027 & -.460 & .646 \\
\hline Family Structure & -.013 & -.219 & .827 \\
\hline $\begin{array}{l}\text { With or Without } \\
\text { Migrant Maids }\end{array}$ & .043 & .848 & .397 \\
\hline Religion (Catholic) & -.069 & -1.351 & .178 \\
\hline Religion (Christian) & -.041 & -.781 & .435 \\
\hline Religion (Buddhism) & .002 & .037 & .970 \\
\hline Religion (Islam) & -.109 & -2.241 & $.026^{*}$ \\
\hline Religion (Other) & -.038 & -.707 & .480 \\
\hline $\begin{array}{c}\text { Occupations } \\
\text { (agriculture, forestry, } \\
\text { fishery, animal } \\
\text { husbandry) }\end{array}$ & -.026 & -.495 & .621 \\
\hline $\begin{array}{l}\text { Occupations } \\
\text { (industries) }\end{array}$ & -.027 & -.430 & .667 \\
\hline $\begin{array}{l}\text { Occupations (low-level } \\
\text { of white-collar office } \\
\text { labors and low-level } \\
\text { military personnel) }\end{array}$ & .028 & .494 & .621 \\
\hline $\begin{array}{l}\text { Occupations (high-level } \\
\text { of white-collar labors, } \\
\text { middle class, high-end } \\
\text { military personnel) }\end{array}$ & -.019 & -.308 & .759 \\
\hline $\begin{array}{c}\text { Occupations } \\
\text { (Bourgeois, freelancers) }\end{array}$ & -.005 & -.072 & .943 \\
\hline $\begin{array}{c}\text { Occupations } \\
\text { (big capitalists) }\end{array}$ & .011 & .222 & .824 \\
\hline $\begin{array}{l}\text { Occupations } \\
\text { (homemaker) }\end{array}$ & -.021 & -.339 & .734 \\
\hline Occupations (none) & .048 & .807 & .420 \\
\hline Marriage (unmarried) & -.012 & -.147 & .883 \\
\hline Marriage (divorced) & -.117 & -2.363 & $.019^{*}$ \\
\hline $\begin{array}{l}\text { Activity Time } \\
\text { (Morning) }\end{array}$ & -.060 & -1.028 & .305 \\
\hline Activity Time (noon) & .077 & 1.333 & .183 \\
\hline $\begin{array}{c}\text { Activity Time } \\
\text { (Afternoon) }\end{array}$ & -.006 & -.095 & .925 \\
\hline $\begin{array}{l}\text { Activity Time } \\
\text { (Midnight) }\end{array}$ & -.047 & -.831 & .407 \\
\hline $\begin{array}{l}\text { Contact Time } \\
\text { (Morning) }\end{array}$ & -.100 & -1.795 & .073 \\
\hline Contact Time (Noon) & .002 & .037 & .970 \\
\hline $\begin{array}{l}\text { Contact Time } \\
\text { (Afternoon) }\end{array}$ & -.015 & .236 & .814 \\
\hline $\begin{array}{l}\text { Contact Time } \\
\text { (Midnight) }\end{array}$ & -.009 & -.156 & .876 \\
\hline $\begin{array}{c}\text { Community residents' } \\
\text { attitude on migrant } \\
\text { workers }\end{array}$ & .121 & 2.444 & $.015^{*}$ \\
\hline
\end{tabular}

Note: The dependent variable $\mathrm{Y}$ is the total score of urban space partitioning. (Please name $\mathrm{Y}$ on your own).
Seeing from Table 3 and the overall regression model, the overall regression model has an explanatory power $(\mathrm{F}=6.437$, $\mathrm{P}<.001$ ), it can effectively explain why migrant workers have $37.3 \%$ variance as migrant workers' impact on urban space partitioning. Among all these, industrial labors' $\beta=-.162,(\mathrm{t}=$ -3.147, $\mathrm{p}<.01$ ) have reached a statistically significance, thus it's an effective forecasting variable. $\beta$ being negative indicates that non-industrial Labors think migrant workers' consumption gathering makes a great impact on urban space partitioning. Bourgeois/freelancers' $\beta=-.181$, $(\mathrm{t}=-2.939, \mathrm{p}<.01)$ have reached a statistically significance, thus, it indicates that people who aren't bourgeois/freelancers tend to think migrant workers' consumption gathering makes urban space partitioning easier. Jobless people's $\beta=-.125$, $(\mathrm{t}=-2.234, \mathrm{p}<.05)$ has reached a statistically significance, thus, it indicated residents who have jobs think migrant workers' consumption gathering makes urban space partitioning easier. We can find the explanation of the results from community residents' jobs: low-level of whitecollar office labors, high-level of white-collar office labors, housekeepers and other jobs, these 4 types of jobs fields have a total of $48.2 \%$ in the communities. It's the composition of the bottom, and they have more direct feelings on changes of daily life. So, they think migrant workers' consumption gathering makes urban space partitioning easier. Additionally, the community residents think the phenomenon has brought changes on its cultural basis, which has reached a statistically significance, thus, it's an effective forecasting variable, $\beta=.276$, $(\mathrm{t}=4.960$, $\mathrm{p}<.001)$. Because $\beta$ is positive, it indicates that the community residents think the phenomenon has brought changes on its cultural basis, at the same time, it also makes urban space partitioning easier. The community residents who think the phenomenon has brought changes on its activity events is $\beta=.344$, ( $\mathrm{t}$ $=5.168, \mathrm{p}<.001)$. Since $\beta$ is positive, it indicates that community residents think things that make changes on activity events, at the same time, also makes urban space partitioning easier. As a result we can see from community resident's attitude reflections, migrant workers' cultural impacts and the impacts on activities, as for urban space partitioning, it's an effective forecasting variable, so the findings are noteworthy.

At the same time, the standardized regression equation is as following:

$\mathrm{Y}=.001$ Gender +.121 Age $+(-.067)$ Educational Level + (-.016) Religion (Catholic) $+(-.079)$ Religion (Christian) +.023 Religion (Buddhism) +.023 Religion (Taoism) $+(-.033)$ Religion (Islam) $+(-.076)$ Occupations (agriculture, forestry, fishery, animal husbandry) $+(-.162)$ Occupations (industries) + $(-.020)$ Occupations (low-level of white-collar office labors and low-level military personnel) + (-.097) Occupations (highlevel of white-collar labors, middle class, high-end military personnel) +-(181) Occupations (Bourgeois, freelancers) +.076 Occupations (big capitalists) $+(-.033)$ Occupations (homemaker) $+(-.125)$ Occupations (none) $+(-.091)$ Marriage (Unmarried) $+(.172)$ Marriage (Married) +.082 Monthly Salary $+(-.088)$ Family Structure $+(-056)$ With or Without Migrant Maids +.010 Activity Time +.036 Contact Time $+.037 \mathrm{X} 1+.276 \mathrm{X} 2$ (cultural changes) $+.033 \mathrm{X} 3+.11 \mathrm{X} 4$ +.344 X5 (changes on activities).

Tainan City, Kaohsiung City and Taichung City's Influencing Factor's Comparison and Explanation

As we can see from Table 4, in the resident's point of view, 
Table 3.

Regression coefficient table.

\begin{tabular}{|c|c|c|c|}
\hline Predictor & $\begin{array}{c}\text { Standardized } \\
\text { Regression } \\
\text { Coefficient } \beta\end{array}$ & $\mathbf{t}$ & Significance \\
\hline Gender & .001 & .024 & .981 \\
\hline Age & .121 & 1.600 & .111 \\
\hline Educational Level & -.067 & -1.182 & .238 \\
\hline Religion (Catholic) & -.016 & -.347 & .729 \\
\hline Religion (Christian) & -.079 & -1.517 & .130 \\
\hline Religion (Buddhism) & .023 & .391 & .696 \\
\hline Religion (Taoism) & .023 & .417 & .677 \\
\hline Religion (Islam) & -.033 & -.712 & .477 \\
\hline $\begin{array}{c}\text { Occupations } \\
\text { (agriculture, forestry, } \\
\text { fishery, animal } \\
\text { husbandry) }\end{array}$ & -.076 & -1.613 & .108 \\
\hline Occupations (industries) & -.162 & -3.147 & $.002^{* *}$ \\
\hline $\begin{array}{c}\text { Occupations } \\
\text { (low-level of white-collar } \\
\text { office labors and } \\
\text { low-level military } \\
\text { personnel) }\end{array}$ & -.020 & -.357 & .721 \\
\hline $\begin{array}{c}\text { Occupations } \\
\text { (high-level of } \\
\text { white-collar labors, } \\
\text { middle class, high-end } \\
\text { military personnel ) }\end{array}$ & -.097 & -1.608 & .109 \\
\hline $\begin{array}{c}\text { Occupations } \\
\text { (Bourgeois, freelancers) }\end{array}$ & -.181 & -2.939 & $.004^{* *}$ \\
\hline $\begin{array}{l}\text { Occupations } \\
\text { (big capitalists) }\end{array}$ & .076 & 1.561 & .120 \\
\hline $\begin{array}{c}\text { Occupations } \\
\text { (homemaker) }\end{array}$ & -.033 & -.564 & .573 \\
\hline Occupations (none) & -.125 & -2.234 & $.026^{*}$ \\
\hline Marriage (unmarried) & -.091 & -.648 & .517 \\
\hline Marriage (married & -.172 & -1.298 & .195 \\
\hline Personal Monthly Salary & .082 & 1.504 & .134 \\
\hline Family Structure & -.088 & -1.747 & .082 \\
\hline $\begin{array}{l}\text { With or Without } \\
\text { Migrant Maids }\end{array}$ & -.056 & -1.187 & .236 \\
\hline Activity time & .010 & .208 & .835 \\
\hline Contact time & .036 & .744 & .457 \\
\hline $\begin{array}{l}\text { X1's changes } \\
\text { on population }\end{array}$ & .037 & .752 & .453 \\
\hline X2's changes on culture & .276 & 4.960 & $.000^{* * * *}$ \\
\hline $\begin{array}{l}\text { X3's changes on } \\
\text { spatial function }\end{array}$ & .033 & .583 & .560 \\
\hline $\begin{array}{c}\text { X4's changes on } \\
\text { socioeconomic status }\end{array}$ & .011 & .164 & .870 \\
\hline $\begin{array}{l}\text { X5's changes } \\
\text { on activities }\end{array}$ & .344 & 5.168 & $.000^{* * *}$ \\
\hline
\end{tabular}

${ }^{*} \mathrm{p}<.05,{ }^{* *} \mathrm{p}<.01,{ }^{* * *} \mathrm{p}<.001, \mathrm{Y}$ : The dependent variable.

the influencing factors between Southeast Asian migrant workers' gathering in the business district and urban cities differ.
Furthermore we can see that Tainan City, Kaohsiung City and Taichung City all have obvious differences on the impact variables. The reasons are as mentioned above in the first paragraph (Section 5.1).

\section{The Results of the Study's Dialogue with Existing Theoretical Research}

The survey's responder's are Filipino and Indonesian transient migrant workers. It's quite different from Peter Marcuse's (2002) study which focuses on how the "Ghetto" area in the US formed "divided cities"; and Ronald van Kempen (2002) in the Netherlands, using "segregation index, SI" "to prove so-called partitioned cities" have become more obvious with time and have developed rapidly. Comparing it with our research method, it is completely different. Even though this survey didn't use the "segregation index, SI" to prove the degree of urban space partitioning in Tainan City, Kaohsiung City and Taichung City, it still has similarities with Brenda Yeoh and Shirlena Huang's (1998) studies about the subjects, which are strategies and types thereof of housework female migrant worker in public spaces in Singapore and it is found that the phenomena of "divided cities" -especially for the gathering and all kinds of consumption activities in shopping malls like "Lucky Plaza". As for some Singaporeans, "Lucky Plaza” has been a "divided city", changing from an "other type of space" to a "hesitant space". I, as the author of this paper, speculate that, when more and more migrant workers gather in the research areas in the future, and community residents have lower links of satisfaction on cultural and spatial influences, then the citizens of these three cities in Taiwan will also view those areas as "divided cities". Thus, it proves Ronald van Kempen’s (2002) studies' notion on "social polarization and urban space partitioning" is correct, including 1) The growing influence of ethnic groups, race and migration, 2) Exclusive of race and class. These two factors can fully describe the "divided cities" phenomena in these three cities.

Basically, the influencing factors of these three cities' Southeast migrant workers' gathering to urban space partitioning, have some factors in common as in the Netherlands and Singapore, which include: The Netherland's economics, population and changes in the socio-cultural factors; Singaporean government's laissez-faire attitude as the role of the government, the tolerance of the community residents and shops, but however, it doesn't have common factors as in Guangzhou, China. If we try to interpret the "de-territorialization" and "reterritorialization" points of views to describe the relation between transnational migration and local spaces, according to the survey's results, the same thing happened which was written in Wu Bi-nar's (2003) thesis. In Chung Shan's research resultsdisplaced Filipino migrant workers used the entering of Christopher church and its surrounding shops to re-territorialize the space. And, as in Pei-Chia Lan's paper (2002), we found out Filipina housework migrant workers perform multiple roles and shifting identities through the front/backstage segregation in social space (working days vs. rest day; home country vs. host country), isolating labor and consumption activities, and the differentiation of temporal horizons (now vs. future) in order to build floating identification. Based on the results of these two research papers, the research of this paper added two more viewpoints: under the concepts of "transnational space" or "space partitioning", we focused on the attitudes of local community residents toward the impact of immigration of different 


\section{K.-H. CHEN}

Table 4.

The attitudes of community residents in Tainan City, Kaohsiung City and Taichung City toward migrant workers' gathering in the business districts to urban space partitioning and comparison among the influencing factors.

\begin{tabular}{cccc}
\hline & Kainan City & Kaohsiung City & Taichung City \\
\hline & & 1) Non-Muslim & 1) Non-industrial labors \\
1) Short residence time & 2) Non-divorced & 3) Non-freelancers \\
Impact variables & 4) Labors
\end{tabular}

cultural groups, in order to describe the "degree of urban space partitioning” better, and at the same time, observing from the local residents points of view, we can explore the influencing factors between Southeast Asian migrant workers' gathering to urban space partitioning.

\section{Psychological Explanations}

Representational Space and Third Space Theory

We also can interpret these consumption patterns and the partitioning of urban space derived from migrant workers' gathering in urban commercial areas from the viewpoint of "representational space of migrant workers in other homeland (Taiwan)”. For migrant workers, Taiwan acts as a relative location, not only in a geographic space of map but also in a social space. Taiwan has been a subject as compared to "other" (migrant workers). In other words, dining room acts as a space "the family take a dinner together"-that is "representation of space" called by Lefebvre also is "second space" called by Soja. This space is not existent for migrant workers. Therefore, "representational space" acts as a bridge linking social life with art and imaginary, has been a struggling space to strive for freedom and disarm. Soja think that "third space" by Lefebvre (1991) has strengthened "governance", "obedience" and "resistance" and he call it "thirds pace" (1996). This is reason why migrant workers usually favored excursion, shopping out and dining out with their friends on weekend. Because they can compete for dignity and human rights via "third space".

\section{Migrant Network}

The result of this research has to be a dialog with the consumption theory, has to extend to all consumption theories, then attempt to create a new consumption theory. From the experience of this research we can discover, through Philippine, Thai, Indonesian, Vietnamese nationality labourers in Tainan county, Tainan city, Kao-hsiung county, Kao-hsiung city commercial district or shopping street's consumption patterns created innovative consumption theory, has to excede Veblen or Simmel's classificational determining consumption viewpoint, neither using Bourdieu stated habitual (habitus) or distinction causing consumption. Rather using Massey's "migrant network" (1996) stand, or Erickson (1996) proposed "network variety", "cultural variety". To create a migrant network, consumption is a very important system, through different consumption events, the whole network becomes operated, in the whole migration process framework, "class" will influence "consumption" and "network", in the meantime consumption and network also mutually influence each other, the relationship between the three is just like above.

Just like this research discovers, the four countries labourers are looking forward to have cell-phone, because they are yearning for "language intimacy", a familiar language can have a kind of emotionally relieving effect, also can be a helping media in the migrant network to individually get acquainted with Taiwan's unfamiliar environment. In the aspect of "Consumption in a specific store”, except for the Vietnamese, the Philippine, the Thai and the Indonesian labourers all generally have their specific consumptional behaviour. The Philippine labourers prefer to consume in [shopping mall], [sport-dress store], [department store], the Thai labourers usually like to choose [Thailand store], [supermarket], [communication/cell phone store], and the Indonesian labourers also usually like to choose [Indonesian store]. There have been influenced by their mother nations' socio-economic and cultural context, traditional consumer s' habits, consumption ability and unique lifestyle and so on. For example, under Western/colonial education and consumerism, the Philippine labourers are used to patronize modern/western-style commercial facilities. Because the nationality of collective life and dinning-in-home, the Thai and the Indonesian labourers are used to patronize the stores which selling homeland commodity. If we explain the differences between the Philippine, the Thai and the Indonesian labourers and the Vietnamese, we can say that when compared to the Vietnamese, the former three have needs to establish their social network and have adequate migrant network. From the interviewee's answer, we know the Vietnamese have not strong need to meet and chat with their friends. And they consider few Vietnamese store are less than Thai or Indonesian store on shopping streets in Taiwan. Featherstone (1991) had the same point of view, thinking in the modern world class-based consumption's influence gets less and less determining, there are more and more facts to confer consumption behaviour, including gender, race, religion, country, migrant network, human relationships, ethnic identity, etc.

\section{Limitations of This Research}

Although we are going to trace back the research to the initial theoretical framework: "The era of globalization and economic dynamism, has created a large-scale flow of migrant workers, it has made a great impact on the urban space in the residential countries - transnational space and partitioning space". By thinking of this theoretical framework, We found out, that the result of this research not only can provide explanatory arguments in the theoretical framework of "global industrial movements-migrant workers gathering and preference choice of space-cross-cultural diversity-the transformation of local consumption spaces-the segmentation of the functions of urban space - the restructuring process of local space”, but it can also be used as a foothold in order to develop more values 
of academic research. Especially the induced outcomes of divided space in the three city's spatial structure, not be considered in this paper. This is the limitation of the paper.

\section{Conclusion}

The following points are the outcomes of this paper:

1) The activity spaces of local residents show that a significant segregation of migrant workers activity spaces, the so-called "independent, divided space" has obviously taken shape. The result is a common phenomenon of Tainan City, Kaohsiung City and Taichung City. However, Taichung City's proportion of this has a higher percentage than that in Tainan City and Kaohsiung City, which is a major discovery of this paper.

2) In Tainan City and Kaohsiung City, community residents have more tolerant attitudes towards the negative impacts of migrant workers gathering in the shopping streets. Comparing the community residents' attitude in Taichung City with Tainan City and Kaohsiung City, their attitudes to migrant workers' gathering are relatively unfriendly. They seem to have a more intense opinion in this issue, and thus they are less friendly and hospitable.

3) The influencing factors' comparison of Southeast Asian migrant workers' gathering in the business districts to urban space partitioning, in regard to community residents, Tainan City, Kaohsiung City and Taichung City all have significant differences. They're all effective forecasting variables which are worthy of attention. Thus we can make the important conclusions that: in community residents' points of view, we can look for residents' opinions from different socio-economic backgrounds, and their attitude toward migrant workers' gathering in the business district to find the influencing factors of Southeast Asian migrant workers' gathering to urban space partitioning. Basically, we can find that these influential factors among the paper are the same as the Netherlands and Singapore, and not the same as Guangzhou, China.

\section{Acknowledgements}

1) The author would like to acknowledge the support of the National Science Council (NSC) of TAIWAN in funding the research on which this paper is based (Project No.: NSC962415-H-024-001-SS2, NSC98-2410-H-024-013-SSS, NSC992410-H-024-029-SSS).

2) This paper has been published in The 2012 International Conference on Asia-Pacific Studies and revised according to the reviews of the consultant.

\section{REFERENCES}

Bureau of Employment and Vocational Training of Council of Labor Affairs (2011). Foreign labors statistics. http://labor.kcg.gov.tw/labor.htm

Chen Kung-Hung (2008). The Formation and Meanings of Southeast Asian Migrant Workers' Ethno-Consumptive Space on Tainan City/ County and Kao-hsiung City/County in Taiwan. Proceedings of International Symposium on City Planning 2008, Chonbuk National University.
Chen Kung-Hung (2011a). Study on south-eastern Asian migrant workers' gathering in urban commercial area and its relations between the partitioning of urban space in Kaohsiung City. Journal of Architecture and Planning, 12, 47-74.

Chen Kung-Hung (2011b). Study on Indonesian migrant workers’ gathering and consumptive activities in urban commercial area and its impacts on urban community spaces in Tainan City. Asia-Pacific Forum, 51, 66-93.

Chen Kung-Hung (2011c). Community residents' attitudes to the impact of migrant workers' gathering and its relations between the partitioning of urban space-Taichung City Commercial Area Case. 2011 Conference of China Geographical Society, National Changhua University of Education, Taiwan.

Chou Cheng-Hung (2003). Migrant labors: A catalyst for rebuilding urban space. Master Thesis, Graduate Institute of Architecture of Tunghai University.

Du, H., \& Li, S. M. (2010). Migrants, urban villages, and community sentiments: A case of Guangzhou, China. Asian Geographer, 27, 93108. http://dx.doi.org/10.1080/10225706.2010.9684155

Erickson, B. H. (1996). Culture, class and connections. The American Journal of Sociology, 102, 217-250.

http://dx.doi.org/10.1086/230912

Featherstone, M. (1991). Consumer culture and postmodernism. London: Sage.

Kempen, Ronald van (2002). Towards partitioned cities in the Netherlands? Changing patterns of segregation in a highly developed welfare state. In P. Marcuse, \& K. Ronald van (Eds.), Of states and cities: The partitioning of urban space (Chapter 5, pp. 88-108). Oxford: Oxford University Press.

Lan Pei-Chia (2002). A transnational topography for the migration and identification of Filipino migrant domestic workers. Taiwan: A Radical Quartwely in Social Studies, 48, 169-219.

Lefebvre, H. (1991). The production of space. Oxford: Blackwell.

Marcuse, P. (2002). The shifting meaning of the black Ghetto in the United States. In P. Marcuse, \& K. Ronald van (Eds.), Of states and cities: The partitioning of urban space (Chapter 6, pp. 109-142). Oxford: Oxford University Press.

Marcuse, P., \& Ronald van, K. (2002). Of states and cities: The partitioning of urban space. Oxford: Oxford University Press.

Massey, D. (1996). What driving Mexico-US migration? A theoretical, empirical, and policy analysis. The American Journal of Sociology, 102, 939-999. http://dx.doi.org/10.1086/231037

Sassen, S. (1988). The mobility of labor and capital: A study in international investment and labor flow. Cambridge: Cambridge University Press. http://dx.doi.org/10.1017/CBO9780511598296

Sassen, S. (1991). The global city: New York, London, Tokyo. Princeton, NJ: Princeton University Press.

Sassen, S. (1996). Losing control: Sovereignty in an age of globalization. New York: Columbia University Press.

Sheu Horng-Yih (2000). The use of space and its effect in a Filipino labor gathering area-Christopher Church Area on Chung-Shane North Road. Master Thesis, Graduate Institute of Architecture of Tamkang University.

Soja, E. (1996). Thirdspace: Journeys to Los Angeles and other realand-imagined places. Oxford: Blackwell.

Wang Chih-Hung (2006). Dis/placed identification and politics of space: The consumptive ethnoscape around Taoyuan Railroad Station. Taiwan: A Radical Quartwely in Social Studies, 61, 149-203.

Wu Bi-Nar (2003). Chung Shan-The formation of a Filipino migrant workers' community space in Taipei. Master Thesis, Institute of Building and Planning of National Taiwan University.

Yeoh, B. S. A., \& Huang, S. (1998). Negotiating public space: Strategies and styles of migrant female domestic workers in Singapore. Urban Studies, 35, 583-602. http://dx.doi.org/10.1080/0042098984925 